\title{
Article
}

\section{The birds and the Bedes: Race, gender, and sexuality in Bede's In Cantica Canticorum}

\author{
Erik Wade \\ Department of English, American, and Celtic Studies, University of Bonn, Bonn, \\ Germany.
}

\begin{abstract}
This article argues that Bede - like modern intersectional analysis believed that identity categories cannot be disentangled or understood in isolation. In Bede's commentary on the Song of Songs, skin color, gender, and religious identity intermix with metaphors of sexuality. These categories coalesce in a monumental lesson on how to read. Bede claims that reading the Song literally - perceiving Black skin, eroticism, gender confusion - means reading like a Jew and prevents readers from seeing the feminine, metaphorical level below the masculine, carnal level. This article suggests that intersectional analysis is akin to much medieval thought rather than being an anachronistic imposition on a historical text. Intersectional analysis can lay bare how medieval theologians saw identity categories as interwoven and interdependent, even while the theologians themselves entrenched hierarchies of race, gender, sexuality, and religious difference. For Bede, Christian interpretation is a continual process of moving from a literal outside (Black, masculine, carnal, sexual) to a metaphorical inside (beautiful, feminine, allegorical, chaste, reproductive). Once inside, however, we - like the bird passing through the hall - must return once again to the outside in an endless movement between layers that echoes theological processes of rumination and blurs the divide between the contemplative and the active life.
\end{abstract}

postmedieval: a journal of medieval cultural studies (2020)11 , 425-433.

https://doi.org/10.1057/s41280-020-00193-6 
1 My thanks to the editors Micah Goodrich, Bre Leake, and Mary Rambaran-Olm for their help and insightful suggestions, and to the ICMS audience, Danielle Allor, Bettina Bildhauer, Suzanne Boswell, Lara Farina, Jessica Hines, Stacy Klein, and the anonymous reviewer for their generous comments on drafts.

2 See Fleming (2016), Lavezzo (2016), Lees and Overing (2009), Matis (2019), and Scheil (2004).

3 See Whitaker (2019) on Blackness and metaphor in later medieval texts.

4 On the history of intersectionality as a concept, see Crenshaw (1989) and Hill Collins and Bilge (2016).

5 On

intersectionality as an analytic of power, see Hill Collins and Bilge (2016), 4-13 and 39-41.
Scholars have begun to pick apart the politics of identity in Bede's work. ${ }^{1}$ They describe a plethora of Bedes: the anti-Judaic polemicist, the amateur Hebraist, the sideliner of women like Abbess Hild. ${ }^{2}$ Yet little scholarship attempts to understand how Judaism, gender, sexuality, and race often intersect in Bede's work. This likely stems from the field's whiteness and failure to learn from Black feminism. This paper uses intersectional analysis to examine Bede's conception of the role of eroticism in interpretation. In his Biblical commentary In Cantica Canticorum, Bede insists that both the Song of Song's eroticism and the Bride's Black skin can only be understood metaphorically. ${ }^{3}$ Bede's commentary - the first widely available systematic exegesis of the Song - had profound influence, in part due to its prominent place in the Glossa Ordinaria (Matis, 2019, 4-25). Both Bede and intersectional analysis suggest that considering a single part of identity in isolation leads to a distorted interpretation. ${ }^{4}$ The Song and Bede thus appear akin to intersectionality's project of centering Black women in analysis (Crenshaw, 1989, 139). After all, the Song's central character is the Bride, a Black woman who symbolizes the Church. Yet Bede, unlike the Black feminists who produced intersectional analysis, does not see the role of power and hierarchy, only the co-construction of identity categories. ${ }^{5}$ At first blush, Bede appears to denounce all sexuality as antithetical to the Bible. The first book of Bede's commentary critiques the fifth-century Italian bishop Julian of Eclanum's Pelagian doctrine of the inherent goodness of human sexuality, which Julian argued by reading the Song literally. However, although Bede refutes physical sexuality, arguing that those who read the Song's eroticism literally are reading like Jews, he nonetheless describes the spiritual world of Christianity using sexual imagery. For Bede, carnal sex betokens spiritual sex. One becomes Christian by learning to read sex and skin color properly and by shedding Jewish and Pelagian 'literalism.' How one reads sex and gender defines one's own racial makeup, and none of these identities can be understood in isolation. In Cantica Canticorum figures Christian maturation as gendered and raced, a movement from Black maleness to sexual femininity, from a carnal Jewish exterior to a spiritually sexual Christian interior.

In his commentaries, Bede usually relies on two of the fourfold interpretations of Scripture: the literal/historical/carnal interpretation and the allegorical/typological interpretation (Brown, 2009, 35-38; Holder, 2011, 10-11), but, when confronted with the Song's sexuality, Bede insists that the Song must not be read literally. He states that 'frequently and everywhere [...], this song testifies that it resounds with nothing carnal or according to the letter [quia nil carnale et iuxta litteram resonet], but wishes that the whole of it be understood spiritually and 
typologically' $(223 ; 337) .{ }^{6}$ He refers to another book of the Bible as 'also a typological book,' suggesting that he saw parts of the Bible as strictly allegorical (39; emphasis mine). This is a step beyond previous Christian interpreters. Origen, for instance, insisted on reading both the literal and spiritual levels of the Song (Origen, 1957, 21-3). Bede's revulsion at the sexual acts becomes his reading practice. He declares that one particular line - 'who will give you to me as my brother sucking my mother's breasts' - shows that one cannot read the Song literally, because 'who among women would suddenly desire that her lover and beloved, whom she has already been desperately in love with as an adult, should not be a young man as he has been, but should be born anew into an infantile state as her brother [sed in aetate infantili fratrem sibi denuo nasci], and be nursed as a little one at her own mother's breasts?' (223; 337-38). He argues that the Song's overt, troublesome sexuality can only be metaphorical. Bede's revulsion becomes a reading method.

Bede states that moments of gender-confusion in the Song - such as the Bride talking about the Bridegroom's 'breasts' - also indicate that the entire text must be read metaphorically: "justly does she refer to the "breasts" of the Bridegroom, which is a part of the female body [muliebris est membrum corporis], in order that at the very beginning of the Song she might clearly show that she is speaking figuratively [figurate se loqui manifestet]' (39; 191-192). Bede follows Origen by reading the Bride as a metaphor for the Church, and the Bridegroom as a figure for Christ, a reading that both Gregory the Great and Bede popularized (Matis, 2019, 4-5). Bede argues for gender essentialism as a reading methodology and presents the Bride as the Church while emphasizing the role of the Church as its doctores: its male preachers and clergy (Matis, 2014). As Hannah Matis argues, Bede's commentary inspired Carolingian clergy to use maternal imagery for themselves to bolster their own authority, including frequent references to drinking wisdom from the 'breasts' of male authority figures (Matis, 2014, especially 373-380; Holder, 2005). ${ }^{7}$

Bede creates his own gender trouble when he argues that the interior and the exterior have distinct genders and that one must move back and forth between them in order to achieve salvation. He sees the inside as the place of women, and the outside as the provenance of men. This gendering of interior and exterior is unique to Bede's reading: Origen, for instance, makes much of the metaphor of the 'outer man' and the 'inner man' in order to explain ideal reading, but Bede genders these levels (Origen, 1957, 25-7). Ideal reading, he asserts, means that one must struggle outside in the masculine carnal level in order to gain access to the feminized metaphorical level within:

the bride always desires to tarry with her beloved in the house, whether on the couch or in some other interior place, which is more appropriate for the female sex, but the Bridegroom himself, as befits the male, is calling his friend rather to work either in the vineyards or in the gardens or in some
6 All In Cantica translations are quoted from Bede (2011), with Latin insertions quoted from Bede (1983). Citations list page numbers for 2011 followed by those for 1983 .

7 On queer genderblurring as a source of authority in medieval English literature, see Pavlinich (2019). 
other outdoor place. Doubtless this is because holy church desires, if possible, always to serve the Lord in the tranquility of worldly peace, and to produce and educate celestial progeny for him [ei caelestem propagare atque educare desiderat], but he arranges for her to be vexed with tribulations at present so that being purified she may attain to eternal joys. $(61 ; 209)$

Alone among Christian exegetes of the Song, Bede insists on the necessity of moving from interior to exterior: Apponius, for instance, saw Christ as the one tarrying on the couch (which represented his tomb) (Apponius, 1997, 314-18). For Bede, one must not move directly to metaphor but work in the literal level first. This seesawing between inside and outside evokes clergy's need - in Bede's characteristic dislike for a life of strict contemplation - to balance the contemplative life and the active life (Holder, 2011, 20-1). This movement also mirrors monastic rumination, where a monk was imagined to ruminate over Scripture like a cow ruminates on grass, regurgitating it to rechew and swallow it anew, a constant movement from inside to outside to inside again (Carruthers, 2008, 205-11). We see how such theological commonplaces - rumination, the vita activa versus the vita contemplativa - held gendered connotations for Bede. Bede suggests that the spiritual interior is the 'more appropriate' place for a woman, while the exterior 'befits the male.' However, Christ urges the Bride to the exterior's 'tribulations' in order to make her worthy of heaven.

For Bede, gender and sexuality cannot be disentangled. While Bede argues sex is a metaphor, it is a metaphor he cannot escape. He presents it as an intrinsic part of the metaphor of Christianity and Christian salvation. The feminine interior is the place of sex: the Church desires to remain inside in order to 'propagare' ['produce/propagate'] spiritual children for her Bridegroom, but she must first pass through the trials of the outside in order to achieve this perfect spiritual sexuality. Reading properly - moving from literal/carnal reading to metaphorical/spiritual reading - nonetheless remains sexual, since Bede aligns metaphor with the feminine body, which Old English writing associates with sexuality (Lees, 1997). Christ Himself moves from inside to outside, for Bede notes that 'he came forth from the Virgin's womb like a bridegroom from his chamber [sponsus suo processit de thalamo] [...] to join [copulandam] the church to himself' $(103-4 ; 243)$. Bede states that Christ came from his mother's

8 See also Bede (1983), 168. womb to 'copulandam' ['couple/join'] with the Church, another sexual image. ${ }^{8}$ A Christian must move outside in order to move inside, moving towards masculinity only in order to achieve the desired state of interior femininity. Bede sexualizes this gender trouble, even for Christ, and he sexualizes reading even as he strives to allegorize it.

Skin color serves as another part of this interlocking system, with the outside imagined as the place of Blackness, while the interior appears beautiful but not precisely aligned with whiteness. Bede's reading stems from Jerome's choice in 
the Vulgate Bible to change the line spoken by the Bride from 'I am black and beautiful' to 'I am black but beautiful' (Ramey, 2014, 49). Origen followed the earlier reading of the line as 'black and beautiful,' but Apponius, Bede, and Gregory used Jerome's translation; Bede likely imitated Gregory, whom Bede quoted on this line (Bede, 1983, 360; Ramey, 2014, 49-50). Jerome marked Blackness as revolting. This anti-Blackness has a long reach; Kim Hall argues that early modern English discourse constructed Blackness - particularly that of Black women - as the opposite of beauty (Hall, 1995). Jerome heightened Blackness's significance as a marker of race for all subsequent Biblical commentators. I am not suggesting that only skin color indicates race. As critical race theorists have shown, race is a social construction not linked to any particular trait (López, 2006; Obasogie, 2014; Omi and Winant, 2015). Geraldine Heng and Sierra Lomuto have also demonstrated that skin color served as only one of the markers of race in the European Middle Ages (Heng, 2018; Lomuto, 2019). Bede sees the Bride's Blackness as reflecting the struggles of the world. Bede writes, "she is undoubtedly "black" with respect to the misfortune of her afflictions [aduersitate], but "beautiful" in the comeliness [decore] of her virtues' $(44 ; 195)$. Bede sees Blackness as exterior and beauty as interior.

Bede suggests that the Bride's Blackness arises from her persecutory environment, rather than being an essential trait:

just as those who remain quietly in the house often have fairer [candidiores] limbs, but the members of those who are employed in the vineyard or garden or any other kind of outdoor work are very frequently darkened [fuscantur] by the sun, so also the more earnestly holy church prepares herself for spiritual combat, the more hotly inflamed are the assaults that the ancient enemy [antiqui hostis] resolves to mount against her. $(46 ; 197)$

The idea of Blackness as an effect of the environment stems from the Classical theory of racial environmental determinism (Snowden, 1970, 25 and 172-7). ${ }^{9}$ Bede describes the difference between body and soul, exterior and interior, male and female, Black and beautiful, through a Classical theory of race. Bede shows that Blackness happens in the masculine outdoors: the same vineyards and garden that he called a male space. Bede claims that, when the Bride says she is 'black but beautiful,' she means, 'I do indeed appear exceedingly vile [Vilis] in the eyes of my persecutors [oculis persequentium], but before God I am shining brightly [refulgeo]' (44; 195). Because the Church's pagan 'persecutors' look with the carnal eyes, they perceive her as Black - as 'vile'- and do not see what God sees with his spiritual sight: her beauty. In Bede's work, Black skin is a metaphor but just seeing the Black skin implicates the viewer racially.

Bede states that the tribulations of the world are lusts that cause the Bride's Blackness. He suggests that God's comfort allows the soul to 'rest a bit from the 
lusts and confusions [cupiditatibus uel perturbationibus] of the world' $(71 ; 217)$. By contrast, he interprets a line about lilies as a reference to 'candidissimos uirginum' [the whitest virgins], who are 'carnis castimonia foris renitent' [bright on the outside with the chastity of their flesh] (Bede, 1983, 228, my translation). Bede argues that seeing the Bride as Black means reading her as sexual, rather than as spiritual. Blackness and sex are the same thing: markers of literal reading.

Bede gathers skin color, sexuality, and bad reading together in the figure of the Jew, a reading of the Song unique to him. Bad reading - reading for sexuality rather than spirituality - marks one as a racial other. Bede associates bad reading with Jews, joining a long anti-Semitic medieval tradition that said that the Jews did not think metaphorically (Lavezzo, 2016, 29-40; Scheil, 2004, 25-50). His other writings describe Jewish thinking as 'puerilis' ['childlike'] (Bede, 1955, 196). Bede ties Jewish refusal of the metaphorical to what he imagines to be Jewish desire for the physical world: 'The Jews were refusing to have this knowledge when they prided themselves on account of the circumcision that was only external [...] because they had set their mind upon a lower and fleshly glory [infimis et in carnis gloria]' $(207-8 ; 325)$. Here, in a text where one must always read on the metaphorical level, Bede equates Jews with sexuality and the carnal level of reading and thus establishes the avoidance of the sexual as a Christian virtue.

Uniquely among early exegetes, Bede argues that the Bride's voice switches between her early life, when she speaks as the Synagogue and her later, mature life, when she is the Church (41-2; 193). Bede repeats the classic Pauline trope of supersession that regards Christianity as a more evolved form of Judaism (Lavezzo, 2016, 22-9). By presenting Judaism as emblematic of literal reading and as the immature form of Christianity, Bede suggests that becoming religiously mature - becoming Christian - requires us to read metaphorically.

Bede sees chastity as essential for metaphorical reading. To him, the Jews act as 'persecutors' of the Church who only see her Black exterior. He describes the 'wars of tribulations [against the Church] from the very same synagogue from which she took her fleshly origin' $(47 ; 197-8)$. The Bride - once held in 'imperio diaboli' [the power of the devil] - became the holy church through chastity and conversion: "She who was formerly called "foreigner" [gentilitas] has now received the name of "church," for she has girded herself [...] with a belt, in order to restrain the loins [lumbos] of her mind from every uncleanness [immunditia]' $(204 ; 322)$. She binds her mind with a belt in order to maintain her chastity, transforming her racially. Bede figures the Synagogue as a sexualized foreigner and the Church as a chaste mother.

However, Bede also describes the Church's maturation as a sexual maturation, depicting the Synagogue as a prepubescent girl without breasts, because she had few followers and could not preach well $(237-8 ; 349)$. Bede argues that breasts symbolize the Church's preachers and teachers, who impart 'lac doctrinae lenioris' [the milk of softer doctrine] to those young in their faith 
(123; 258). The Church's breasts symbolize her maturity as an institution of preaching and conversion. ${ }^{10}$ Bede represents a church's ability to convert people as a sign of sexual maturity and metaphorical motherhood. It is Bede's innovation to make the prepubescent girl the Synagogue and to map sexual maturation onto Christian supersession. For Bede, Christian supersession means a movement from a pre-sexual childhood (a childhood also sexualized and in need of restraint with a belt) to a sexual and reproductive adulthood.

Revulsion - at physical sexuality and gender blurring - is a reading practice, one that marks race. Yet Bede suggests that revulsion is a necessary part of becoming Christian. While Bede directs us away from the literal level, his decision nonetheless to use racial, sexual, and gendered language suggests that he saw that language as part of the complex process of Christian preaching and development that he thought the Song describes. Bede argues that seemingly negative attributes, like sexuality and Blackness, are necessary for spiritual development. The outside is a place of tribulations and of Blackness that the Bride must pass through in order to become pure, saved, and beautiful. One must become Black, in Bede's account, in order to become beautiful, become masculine in order to become feminine. Christian allegorical reading allows Christians to 'transcend' Jewish reading practices by moving back and forth through both darkness and beauty. The Church representing us all - must rise from her couch and go outside to turn dark through the tribulations of the carnal masculine world. That enables her return to allegory and beautiful femininity and fashions a chaste, mature interior.

Intersectional analysis allows us to decipher Bede. It allows us to realize that his own text emphasizes how identity categories interlock. It allows us to recognize that, in Bede's text, 'Black women are theoretically erased,' just as Kimberlé Crenshaw describes in modern texts (Crenshaw, 1989, 139): for Bede, Blackness is without and femininity within, rendering Black women an impossibility in a Biblical book that purports to present a Black woman speaking. Intersectional analysis enables us to see that Bede comes close to an intersectional understanding of identity but only in the service of hierarchy. The monk's tools, it seems, cannot dismantle the monastery.

Bede's treatise draws back the curtain on how medieval metaphors of Christian spiritual progress often depended on intersecting racial and gender hierarchies. Now, well over a millennium later, we are still learning how to read him.

Funding Open Access funding provided by Projekt DEAL.
10 Compare to the Collectanea Pseudo-Bedae: 'Tell me, please, who is the woman who offers her breasts to innumerable sons, and who pours forth as much as she is sucked? This woman is wisdom' (Bayless and Lapidge, 1998, 122-3).

\section{Open Access}

This article is licensed under a Creative Commons Attribution 4.0 International License, which permits use, sharing, adaptation, distribution and reproduction 
in any medium or format, as long as you give appropriate credit to the original author(s) and the source, provide a link to the Creative Commons licence, and indicate if changes were made. The images or other third party material in this article are included in the article's Creative Commons licence, unless indicated otherwise in a credit line to the material. If material is not included in the article's Creative Commons licence and your intended use is not permitted by statutory regulation or exceeds the permitted use, you will need to obtain permission directly from the copyright holder. To view a copy of this licence, visit http://creativecommons.org/licenses/by/4.0/.

\section{About the Author}

Erik Wade is a Wissenschaftlicher Mitarbeiter in the Department for English, American, and Celtic Studies at the University of Bonn. He traces the global sources of conceptions of sexuality and race in Old English literature. His writing appears in Exemplaria, JEGP, The Journal of Medieval Worlds, The Medieval Globe, and other venues. A book co-authored with Mary RambaranOlm, Race in Early Medieval England, is out this year from Cambridge University Press (E-mail: ewade@uni-bonn.de).

\section{References}

Apponius. 1997. Commentaire Sur Le Cantique Des Cantiques, Tome I. Paris, France: Les Éditions Du Cerf.

Bayless, M. and M. Lapidge, eds. 1998. Collectanea pseudo-Bedae. Dublin, Ireland: Dublin Institute for Advanced Studies.

Bede. 1955. Homelia II. In Bedae Venerabilis Opera, Pars III., 184-378, ed. D. Hurst. Turnhout, Belgium: Brepols.

Bede. 1983. In Cantica Canticorum. In Bedae Venerabilis Opera, Pars II, 2B, 165-375, ed. D. Hurst. Turnhout, Belgium: Brepols.

Bede. 2011. On the Song of Songs and Selected Writings, trans. A. Holder. Mahwah, NJ: Paulist Press.

Brown, G.H. 2009. A Companion to Bede. Woodbridge, UK: Boydell Press.

Carruthers, M. 2008. The Book of Memory: A Study of Memory in Medieval Culture. Cambridge, UK: Cambridge University Press.

Crenshaw, K. 1989. Demarginalizing the Intersection of Race and Sex: A Black Feminist Critique of Antidiscrimination Doctrine, Feminist Theory, and Antiracist Politics. University of Chicago Legal Forum 1: 139-67.

Fleming, D. 2016. Hebraeam scire linguam: Bede's Rhetoric of the Hebrew Truth. In Imagining the Jew in Anglo-Saxon Literature and Culture, 63-78, ed. S. Zacher. Toronto, Canada: University of Toronto Press. 
Hall, K.F. 1995. Things of Darkness: Economies of Race and Gender in Early Modern England. Ithaca, NY: Cornell University Press.

Heng, G. 2018. The Invention of Race in the European Middle Ages. Cambridge, UK: Cambridge University Press.

Hill Collins, P. and S. Bilge. 2016. Intersectionality. Cambridge, UK: Polity Press.

Holder, A.G. 2005. The Feminine Christ in Bede's Biblical Commentaries. In Bède Le Vénérable: Entre tradition et postérité, eds. S. Lebecq, M. Perrin, and O. Szerwiniak, 109-18. Villeneuve d'Ascq, France: Publications de l'Institut de recherches historiques du Septentrion.

Holder, A. 2011. Introduction. In On the Song of Songs and Selected Writings, trans. A. Holder, 1-32. Mahwah, NJ: Paulist Press.

Lavezzo, K. 2016. The Accommodated Jew: English antisemitism from Bede to Milton. Ithaca, NY: Cornell University Press.

Lees, C.A. 1997. Engendering Religious Desire: Sex, Knowledge, and Christian Identity in Anglo-Saxon England. The Journal of Medieval and Early Modern Studies 27(1): 17-45.

Lees, C.A. and G.R. Overing. 2009. Double Agents: Women and Clerical Culture in AngloSaxon England. Cardiff, UK: University of Wales Press.

Lomuto, S. 2019. The Mongol Princess of Tars: Global Relations and Racial Formation in The King of Tars (c. 1330). Exemplaria 31 (3): 171-92.

López, I.H. 2006. White by Law: The Legal Construction of Race. New York: New York University Press.

Matis, H.W. 2014. Early-Medieval Exegesis of the Song of Songs and the Maternal Language of Clerical Authority. Speculum 89 (2): 358-81.

Matis, H.W. 2019. The Song of Songs in the Early Middle Ages. Boston, MA: Brill.

Obasogie, O.K. 2014. Blinded by Sight: Seeing Race Through the Eyes of the Blind. Stanford, CA: Stanford University Press.

Omi, M., and H. Winant. 2015. Racial Formation in the United States. New York: Routledge.

Origen. 1957. The Song of Songs: Commentary and Homilies. Trans. and ed. R.P. Lawson. Westminster, MD: The Newman Press.

Pavlinich, E.J. 2019. Queer Authority in Old and Middle English Literature. PhD dissertation, University of South Florida.

Ramey, L.T. 2014. Black Legacies: Race and the European Middle Ages. Gainesville, FL: University Press of Florida.

Scheil, A.P. 2004. The Footsteps of Israel: Understanding Jews in Anglo-Saxon England. Ann Arbor, MI: University of Michigan Press.

Snowden, F.M. 1970. Blacks in Antiquity: Ethiopians in the Greco-Roman Experience. Cambridge, MA: The Belknap Press of Harvard University Press.

Whitaker, C.J. 2019. Black Metaphors: How Modern Racism Emerged from Medieval Race-Thinking. Philadelphia, PA: University of Pennsylvania Press.

Publisher's Note Springer Nature remains neutral with regard to jurisdictional claims in published maps and institutional affiliations. 